\title{
Infection process of Fusarium oxysporum f. sp. phaseoli on resistant, intermediate and susceptible bean cultivars
}

\author{
Alisson C. Pereira1, Maria Fernanda A. Cruz ${ }^{2}$, Trazilbo J. Paula Júnior ${ }^{3}$, Fabrício A. Rodrigues ${ }^{4}$, José \\ Eustáquio S. Carneiro ${ }^{5}$, Rogério F. Vieira ${ }^{3}$ \& Pedro Crescêncio S. Carneiro ${ }^{2}$
}

${ }^{1}$ Programa de Pós-Graduação em Genética e Melhoramento, Universidade Federal de Viçosa, 36570-000, Viçosa, MG, Brazil; ${ }^{2}$ Departamento de Biologia Geral, Universidade Federal de Viçosa, 36570-000, Viçosa, MG, Brazil; ${ }^{3}$ EPAMIG, Vila Gianetti 47, 36570-000, Viçosa, MG, Brazil; ${ }^{4}$ Departamento de Fitopatologia, Universidade Federal de Viçosa, 36570-000, Viçosa, MG, Brazil; ${ }^{5}$ Departamento de Fitotecnia, Universidade Federal de Viçosa, 36570-000, Viçosa, MG, Brazil

Author for correspondence: José Eustáquio S. Carneiro, e-mail: jesc@ufv.br

\begin{abstract}
The objective of this study was to understand the infection process of Fusarium oxysporum f. sp. phaseoli (Fop) in bean cultivars classified as resistant (Manteigão Fosco 11), intermediate (VP8) and susceptible (Meia Noite). Plants of the three cultivars were inoculated at 10 days after emergence with a suspension of $1 \times 10^{6}$ conidia of Fop per mL. At 43 days after the inoculation, stem segments were observed with a scanner electronic microscope. The cultivars Manteigão Fosco 11 and VP8 presented an occluding material in the xylem vessels, which may have restricted tissue colonization by Fop. The resistance of bean cultivars to Fop seemed also to be explained by structural differences in the xylem tissue.
\end{abstract}

Key words: Phaseolus vulgaris, Fusarium wilt, host defense.

The fungus Fusarium oxysporum Schlecht. f. sp. phaseoli Kendrick \& Snyder (Fop) is the causal agent of the Fusarium wilt on common beans (Phaseolus vulgaris L.) and is present in all the regions that produce beans in the world (Alves-Santos et al., 2002; Abawi \& Pastor-Corrales, 1990; Schwartz \& McMillan, 1989; Buruchara \& Camacho, 2000). The inadequate rotation of cultures, especially in areas irrigated with central pivot, the lack of preventive measures of control of the pathogen dissemination and the increase of soil compaction made the Fusarium wilt one of the most important bean diseases in Brazil (Paula Júnior et al., 2006).

The dark, thick-walled chlamydospores are the longterm survival structures in soil (Abawi \& Pastor-Corrales, 1990). Management practices alone may not be enough to keep the disease in low levels of intensity. Thus, the most efficient and viable alternative for the control of this disease is the use of resistant cultivars (Abawi, 1989; Abawi \& Pastor-Corrales, 1990; Paula Júnior et al., 2006).

The pathogen is capable of penetrating intact root tissue, although penetration of older parts of root and hypocotyl tissue also occurs, usually through wounds or natural openings (Abawi, 1989; Dongo \& Müller, 1969; Duque \& Müller, 1969). After penetration, hyphae of Fop move inter- and intracellularly and invade the xylem vessels (Mace et al., 1981). The fungus is confined to xylem vessels until the later stages of disease development, although limited invasion of the adjacent tissues may occur; growth of hyphae and transportation of microconidia in the xylem vessels are observed in susceptible cultivars (Abawi, 1989). On the other hand, in resistant plants the colonization between adjacent xylem vessels is restricted, probably as a result of chemical and structural alterations (Mace et al., 1981), including vascular occlusion by the formation of gel plugs, tyloses, deposition of additional wall layers and infusion of these structures with phenols and other metabolites (Mace et al., 1981).

Although there are some reports about the differences in the histopathology of stem tissues from resistant and susceptible bean cultivars infected by Fop, detailed studies that approach the infectious process in plant tissues are scarce, especially comparing the reactions of resistant, intermediate and susceptible cultivars. Therefore, the purpose of the present study was to understand the infection process of Fop in resistant, intermediate and susceptible bean plants.

The Fop isolate was collected in Coimbra (Minas Gerais, Brazil) from bean plants (cv. Meia Noite), which exhibited typical symptoms of the Fusarium wilt, according to the procedures described by Dhingra \& Sinclair (1995). After obtaining pure cultures, a monosporic isolate (FOPUFV-01) was produced according to Fernandes (1993) and used to inoculate the plants.

An experiment was carried out in greenhouse to confirm the reaction of the bean cultivars Manteigão Fosco 11 (resistant), VP8 (intermediate) and Meia Noite (susceptible) to the infection by Fop. The experiment was installed in a completely randomized design with three 
repetitions. The plot was represented by one pot with three plants. A pot with three plants was used as control; in this case, distilled water was used instead of a suspension of conidia for the inoculation.

For the inoculum production, mycelium discs $(0.4 \mathrm{~cm}$ diameter) from a growing colony of $F o p$ were placed in Petri dishes containing potato-dextrose-agar (PDA), which were incubated at $24^{\circ} \mathrm{C}$ during 10 days under continuous light. The following inoculation methodology was used: seeds of each cultivar were disinfected in a solution of hypochlorite $2 \%$ during $1 \mathrm{~min}$, pre-germinated in germtest paper at $25^{\circ} \mathrm{C}$ and humidity of $100 \%$ for $24 \mathrm{~h}$. After that, the seedlings were transplanted to trays containing substrate (Tropstrato $\mathrm{HT}^{\circ}$, Vida Verde), which were kept in greenhouse. Ten days after the sowing, the plants were carefully taken from the trays and their roots were washed in tap water. Approximately $1 / 3$ of the roots were cut with scissors and discarded; the remaining roots were immersed in a suspension of macro and microconidia of Fop $\left(1 \times 10^{6}\right.$ conidia $\left.\mathrm{mL}^{-1}\right)$ during $5 \mathrm{~min}$. After this period, the plants were transplanted to plastic pots containing $2.5 \mathrm{~L}$ of the substrate and kept in greenhouse. At 10 days after the inoculation (dai), $1.0 \mathrm{~g}$ of $\mathrm{N}-\mathrm{P}_{2} \mathrm{O}_{5}-\mathrm{K}_{2} \mathrm{O}$ (8:28:16) was added to the pots.

The severity of Fusarium wilt was evaluated at 21 dai (Pereira et al., 2008), according to the scale of nine levels proposed by Pastor-Corrales \& Abawi (1987), in which: 1 - no visible symptoms; 3 - one to three leaves, representing no more than $10 \%$ of the total foliage, are wilted and chlorotic; 5 - approximately $25 \%$ of leaves and branches exhibit wilting and chlorosis; 7 - approximately $50 \%$ of leaves and branches exhibit wilting and chlorosis; 9 - approximately $75 \%$ or more of the leaves and branches exhibit wilting, chlorosis and defoliation, eventually with plant death.

A second experiment was carried out to study the infection process of Fop in plants of the bean cultivars Manteigão Fosco 11, VP8 and Meia Noite. Plants of these cultivars were inoculated and kept in greenhouse as previously described. At 10 dai, two plants from each cultivar were collected in interval of three days. The roots were discarded and the stems were washed in tap water. Then, the stems were segmented in pieces of $1.0 \mathrm{~cm}$, with the purpose of monitoring the colonization of the stem tissues by Fop and selecting the segments that presented the transition between healthy and diseased tissue. From one plant, small fragments of approximately $0.5 \mathrm{~cm}$ length from the stem segments were removed, disinfected and placed in Petri dishes containing PDA. The segments of a second plant were identified and preserved in microtubes containing $2.0 \mathrm{~mL}$ of alcohol $70 \%$ and stored at $4{ }^{\circ} \mathrm{C}$. The fragments from each stem segment were transferred to flasks containing glutaraldehyde at $2.5 \%$ in sodium cacodylate buffer $0.1 \mathrm{M}\left(\mathrm{pH} \mathrm{7.2)}\right.$ and stored at $4^{\circ} \mathrm{C}$. After one week, the fragments were washed four times with buffer of sodium cacodylate during $10 \mathrm{~min}$ and post-fixated with osmium tetroxide at $1 \%$ also in sodium cacodylate buffer
$0.1 \mathrm{M}(\mathrm{pH} 7.2)$ for two hours at room temperature (Curvelo et al., 2010). After that, the samples were dehydrated in alcoholic series of $30,50,70,80,95$ and $100 \%$ with intervals of $10 \mathrm{~min}$ between the exchanges, performing three passages in the last concentration in the same interval of time. After dehydration, the fragments were submitted to drying at critical point using the "critical point dryer" model CPD 020 (Bal-Tec, Balzers) and set over aluminum metallic supports covered with double-faced scotch tape (Curvelo et al., 2010). Then, all the fragments were covered with colloidal gold by metallization in the device "sputter coater" linked to a "freezing drying unit" model FDU010 (Bal-Tec, Balzers). The fragments were examined in the electronic scanning microscope, model Leo 1430 VP (Carl Zeiss), operating at $10 \mathrm{kV}$, in order to obtain the electromicrographies. Fragments of stem tissues from noninoculated plants of the three cultivars were also examined for comparisons purposes.

In the first experiment, the mean severity levels of Fusarium wilt were 1.1 for Manteigão Fosco 11, 6.0 for VP8 and 8.9 for Meia Noite. These results confirm that the cultivars Manteigão Fosco 11, VP8 and Meia Noite are respectively resistant, intermediate and susceptible to Fop. The yellowing and wilt of plants of Meia Noite were first observed at 15 dai. Other observed symptoms were stunting, vascular discoloration and necrosis of the stem tissues. At 21 dai, most of the Meia Noite plants were completely dry and dead. Vascular discoloration of stem tissues indicating the colonization by Fop was observed in plants of VP8 at 21 dai, but not in plants of Manteigão Fosco 11. Plants of both cultivars became somewhat chlorotic and suffered less reduction in growth compared to the non-inoculated plants. The symptoms were more intense in plants of VP8 than in those of Manteigão Fosco 11.

In the second experiment, the reaction of Manteigão Fosco 11, VP8 and Meia Noite to the inoculation with Fop was similar to the observed in the first experiment, although disease development was slower. The yellowing and wilt symptoms of plants of Meia Noite were first observed at 25 dai. Only at 46 dai, most of the plants of this susceptible cultivar were dead. These variations in the disease development between experiments might be caused by differences in temperature. In the first experiment, the maximum temperature was $30.4^{\circ} \mathrm{C}$ and the minimum was $18.9^{\circ} \mathrm{C}$ while in the second experiment they were $24.3^{\circ} \mathrm{C}$ and $10.2^{\circ} \mathrm{C}$, respectively. The temperatures during the first experiment were more favorable to the infection by Fop and, consequently, to symptoms development than in the second experiment. The optimum temperature for the development of $F o p$ is $28^{\circ} \mathrm{C}$, but the most severe symptoms of Fusarium wilt may occur at $20^{\circ} \mathrm{C}$ (Ribeiro \& Hagedorn, 1979).

Scanning electron micrographs of stem tissues of non-inoculated and inoculated plants of Manteigão Fosco 11 (Figures 1A-E), VP8 (Figures 2A-D) and Meia Noite (Figures 3A-D) were obtained. Fop was re-isolated from the inoculated plants, even from the resistant cultivar 

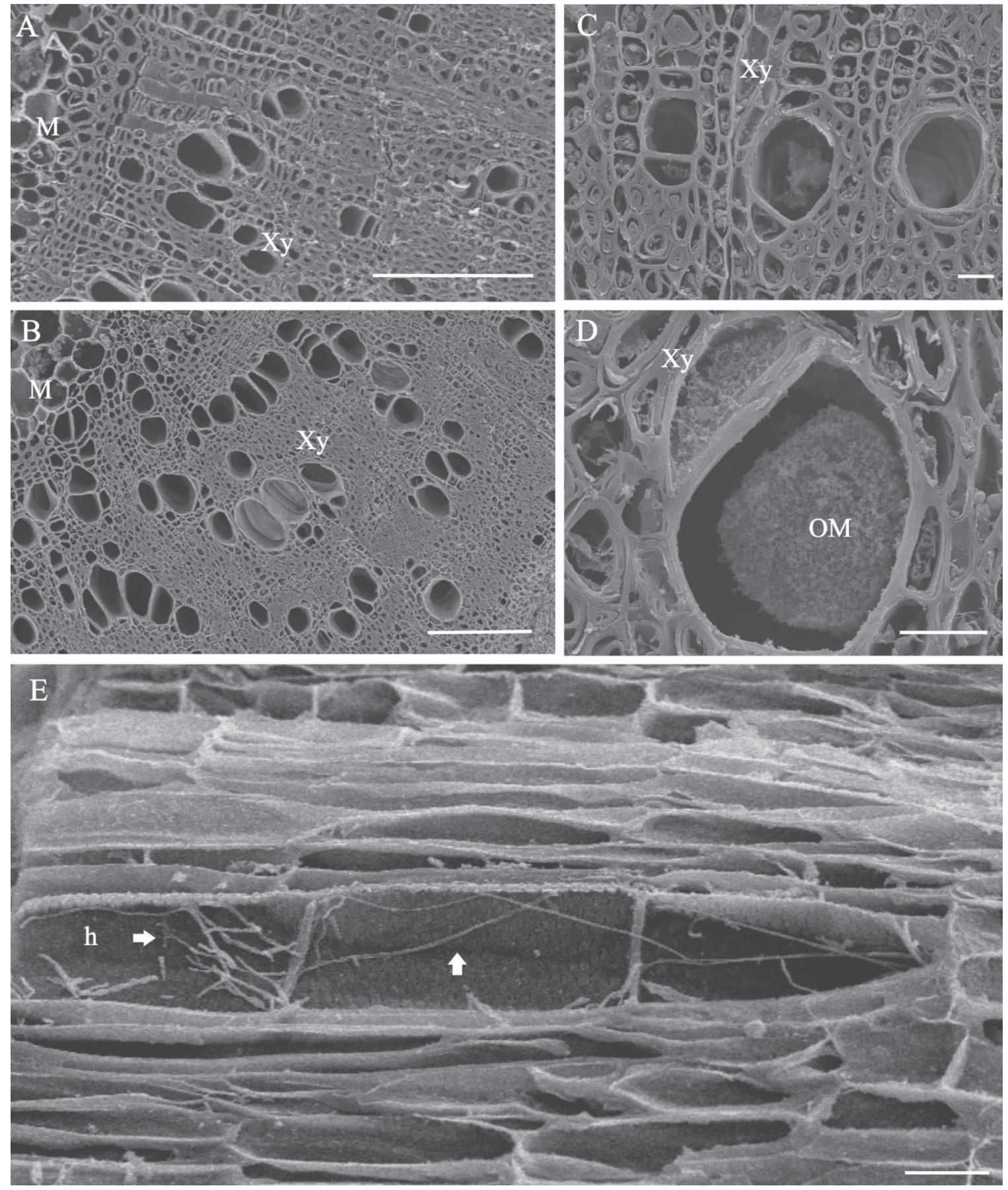

FIGURE 1 - Scanning electron micrographs of stem tissues of plants of the bean cultivar Manteigão Fosco 11 noninoculated and inoculated with Fusarium oxysporum f. sp. phaseoli (Fop). A. Transversal cut of stem from non-inoculated plant; B. Transversal section of stem at 43 days after inoculation with Fop; C. Xylem vessel with occluding material; D. Detail of the xylem vessel with occluding material; E. Longitudinal section of stem containing hyphae of Fop in xylem vessels. $\mathrm{M}=$ medulla, $\mathrm{Xy}=$ xylem, $\mathrm{h}=$ hyphae of Fop and $\mathrm{OM}=$ occluding material. $\mathrm{Bars}: \mathrm{A}=200 \mu \mathrm{m}, \mathrm{B}$ and $\mathrm{C}=20$ $\mu \mathrm{m}$, and $\mathrm{D}=30 \mu \mathrm{m}$.

Manteigão Fosco 11, in which Fop structures were observed in the xylem vessels (Figure 1E), although the plants did not present any wilt symptom. In studies involving selection of bean cultivars resistant to Fusarium wilt, Dongo \& Müller (1969) and Ribeiro \& Ferraz (1984) also re-isolated Fop from stem tissues of plants of genotypes without external disease symptoms.

An occluding material was observed in the xylem vessels of inoculated plants of Manteigão Fosco 11 (Figures 1C-D) and VP8 (Figure 2C), but not in the xylem vessels of 

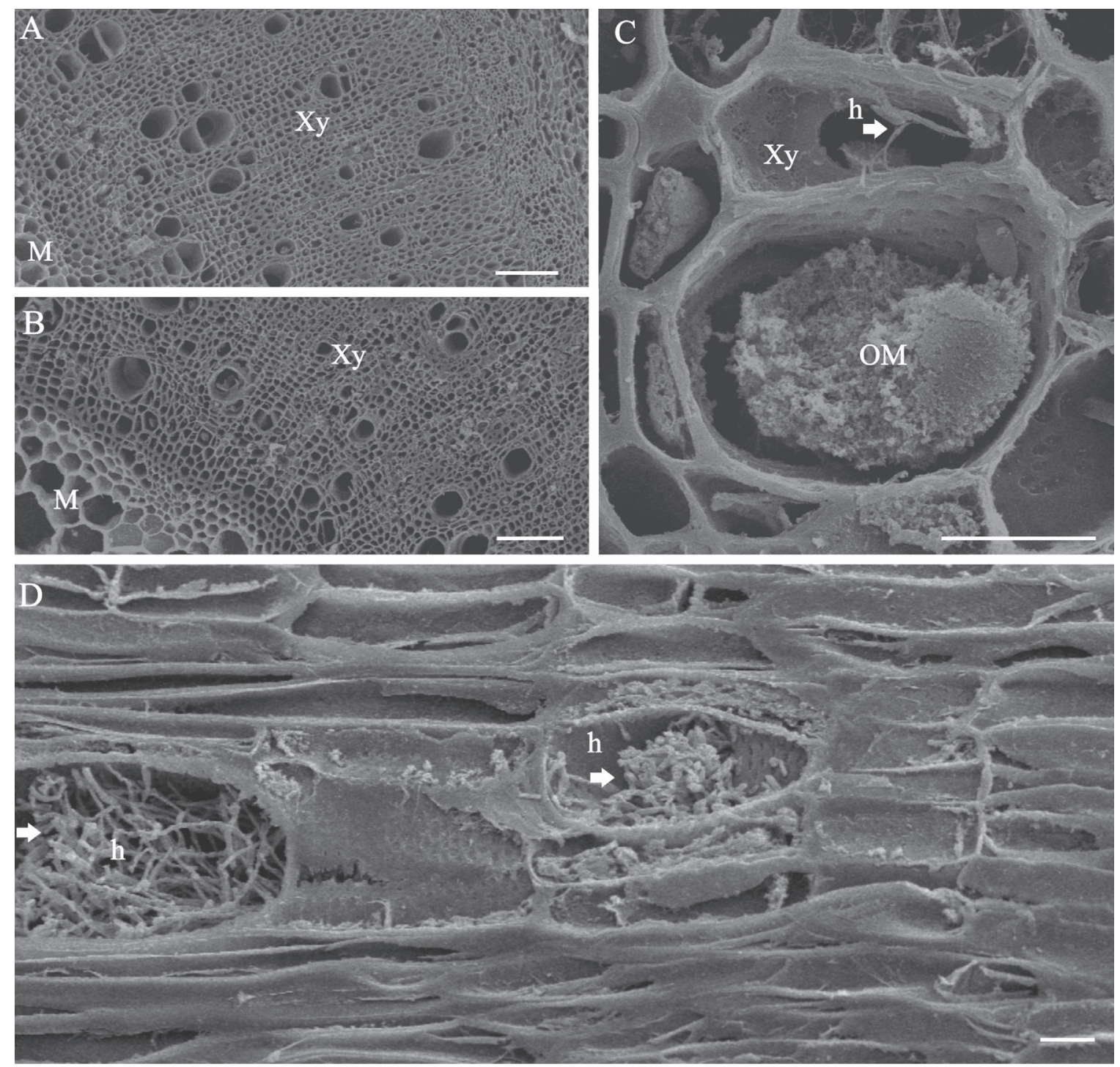

FIGURE 2 - Scanning electron micrographs of stem tissues of plants of the bean cultivar VP8 non-inoculated and inoculated with Fusarium oxysporum f. sp. phaseoli (Fop). A. Transversal cut of stem from non-inoculated plant; B. Transversal section of the stem at 43 days after inoculation with Fop; C. Xylem vessel containing both occluding material and hyphae of Fop; D. Longitudinal section of the stem with massive quantity of hyphae. $\mathrm{M}=$ medulla; $\mathrm{Xy}=\mathrm{xylem}$; $\mathrm{h}$ and arrows $=$ hyphae of Fop and $\mathrm{OM}=$ occluding material. Bars: $\mathrm{A}=100 \mu \mathrm{m}, \mathrm{B}=10 \mu \mathrm{m}$ and $\mathrm{C}=20 \mu \mathrm{m}$.

the susceptible cultivar Meia Noite (Figure 3). The occluding material was not observed in the xylem vessels of the noninoculated plants. The absence of occluding material in noninoculated plants of Manteigão Fosco 11 and VP8 suggests that this material is produced in response to the infection by Fop in cultivars with some level of resistance. Taking into consideration the basal resistance of Manteigão Fosco 11 and VP8 to the infection by Fop, it is suggested that the occluding material may be involved in the resistance of these cultivars against infection by Fop. Mace et al. (1981) suggested that the colonization of the pathogen is restricted in the xylem vessels of resistant cultivars. In other crops than beans, chemical and structural alterations in host tissue have been reported for resistant plants, including formation of gel plugs (Bishop \& Copper, 1984), tyloses (Bishop \& Copper, 1984; Van der Molen et al., 1987) and the presence of substances in the xylem vessels (Shi et al., 1992; Hall et al., 2011). However, the occluding material that was observed seems to be not related to any of the substances reported by those authors.

The presence of Fop hyphae in the xylem vessels was more pronounced in the stem tissues of VP8 than in Manteigão Fosco 11 plants (Figures 1E, 2D). In the stem tissues of Meia Noite, several xylem vessels were completely fulfilled with Fop hyphae and the xylem cell walls were degraded (Figures 3B-D). A great amount of hyphae of Fop was also observed in the xylem vessel (Figure 3D). Bishop \& Copper (1983) also reported that the degradation of the 

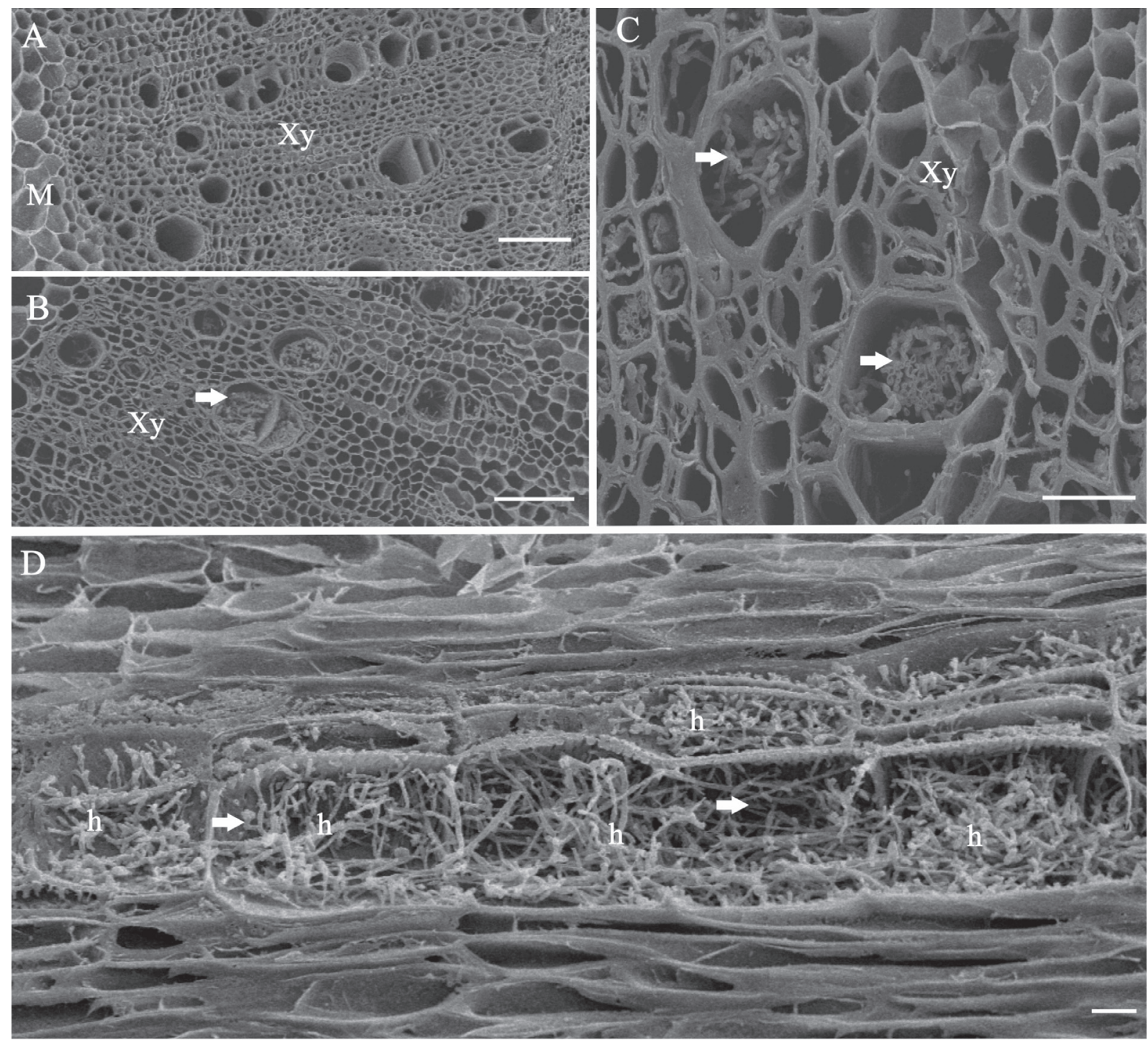

FIGURE 3 - Scanning electron micrographs of stem tissues of plants of the bean cultivar Meia Noite non-inoculated and inoculated with Fusarium oxysporum f. sp. phaseoli (Fop). A. Transversal cut of stem from non-inoculated plant; B. Transversal section of the stem at 43 days after inoculation with Fop; C. Xylem vessel fulfilled with Fop hyphae; D. Longitudinal section of the stem with massive quantity of hyphae and destruction of the cell wall. $\mathrm{M}=$ medulla; $\mathrm{Xy}=\mathrm{xylem}$, and $\mathrm{h}$ and arrows $=$ hyphae of Fop. Bars: A $=100 \mu \mathrm{m}, \mathrm{B}=30 \mu \mathrm{m}$ and $\mathrm{C}=20 \mu \mathrm{m}$.

xylem cell walls after frequent penetration of hyphae favored the infection of susceptible tomato cultivars by F. oxysporum f. sp. lycopersici and of susceptible pea cultivars by $F$. oxysporum f. sp. pisi.

In the stem tissues samples of the resistant cultivar Manteigão Fosco 11 (Figure 1), the xylem was somewhat more compact and the amount of Fop hyphae colonizing the xylem vessels was clearly lower in comparison to the other cultivars (Figures 2 and 3). Other studies have also suggested that the host resistance to the infection by pathogens that colonize the xylem may be linked to the thickening of the cell walls. Hall et al. (2011) compared cotton cultivars moderately resistant and susceptible to $F$. oxysporum f. sp. vasinfectum and found a more pronounced thickening of the xylem cell walls of the moderately resistant plants. Based on the results obtained on the present study, a plausible hypothesis for the resistance of cultivar Manteigão Fosco 11 to infection by Fop is that the xylem cell walls seemed to be ticker in comparison to the other cultivars.

\section{ACKNOWLEDGEMENTS}

F.A. Rodrigues, J.E.S. Carneiro, T.J. Paula Júnior and P.C.S. Carneiro thank Conselho Nacional de Desenvolvimento Científico e Tecnológico - CNPq for 
their fellowships. A.C. Pereira and M.F.A. Cruz were supported by CNPq. This study was financed by CNPq and Fundação de Amparo à Pesquisa do Estado de Minas Gerais - FAPEMIG.

\section{REFERENCES}

Abawi GS (1989) Root rots. In: Schwartz HF, Pastor-Corrales MA (Eds.) Bean production problems in the tropics. $2^{\text {nd }} E d$. Cali Colombia. CIAT. pp. 105-157.

Abawi CS, Pastor-Corrales MA (1990) Root rots of bean in Latin American and Africa: diagnosis, research methodologies, and management strategies. Cali Colombia. CIAT.

Alves-Santos FM, Cordeiro-Lopez L, Sayagués JM, MartínDomingues R, Garcia-Benavides P, Crespo MC, Días-Domingues JM, Eeslava AP (2002) Pathogenicity and race characterization of Fusarium oxysporum f. sp. phaseoli isolates from Spain and Greece. Plant Pathology 51:605-611.

Bishop CD, Cooper RM (1983) An ultrastructural study of vascular colonization in three vascular wilt diseases. Physiological Plant Pathology 23:323-343.

Bishop CD, Cooper RM (1984) Ultrastructure of vascular colonization by fungal wilt pathogens. Physiological Plant Pathology 24:277-289.

Buruchara RA, Camacho L (2000) Common bean reaction to Fusarium oxysporum f. sp. phaseoli, the cause of severe vascular wilt in Central Africa. Journal of Phytopathology 148:39-45.

Curvelo CRS, Rodrigues FA, Berger PG, Rezende DC (2010) Microscopia eletrônica de varredura do processo infeccioso de Ramularia areola em folhas de algodoeiro. Tropical Plant Pathology 35:108-113.

Dhingra OD, Sinclair JB (1995) Basic Plant Pathology Methods. New York NY, USA. CRS Press.

Dongo SL, Müller LE (1969) Estudios sobre la patogenicidad de Fusarium osysporum f. sp. phaseoli en el frijol. II. Pruebas varietales. Turrialba 19:82-90.

Duque SL, Müller LE (1969) Estudio sobre la patogenicidad de Fusarium oxysporum f. sp. phaseoli en frijol. I. Patogenesis histología sintomatologica. Turrialba 19:71-81.
Fernandes MR (1993) Manual para Laboratório de Fitopatologia. Passo Fundo RS, Brazil. Embrapa Trigo.

Hall C, Heath R, Guest DI (2011) Rapid and intense accumulation of terpenoid phytoalexins in infected xylem tissues of cotton (Gossypium hirsutum) resistant to Fusarium oxysporum f. sp. vasinfectum. Physiological and Molecular Plant Pathology 76:182188.

Mace ME, Bell AA, Beckman CH (1981) Fungal wilt diseases of plants. New York NY, USA. Academic Press.

Nascimento SRC, Kurozawa C, Maringoni AC (1995) Avaliação de raças fisiológicas de Fusarium oxysporum f. sp. phaseoli. Fitopatologia Brasileira 20:214-217.

Pastor-Corrales MA, Abawi GS (1987) Reactions of selected bean germplasms to infection by Fusarium oxysporum f. sp. phaseoli. Plant Disease 71:990-993.

Paula Júnior TJ, Lobo Júnior M, Sartorato A, Vieira RF, Carneiro JES, Zambolim L (2006) Manejo integrado de doenças do feijoeiro em áreas irrigadas - Guia Técnico. Viçosa MG, Brazil. EPAMIGCTZM.

Pereira MJZ, Ramalho MAP, Abreu AFB (2008) Estratégias para eficiência da seleção de feijoeiro quanto à resistência à murcha-defusário. Pesquisa Agropecuária Brasileira 43:721-728.

Ribeiro CAG, Ferraz S (1984) Resistência varietal do feijoeiro (Phaseolus vulgaris L.) a Fusarium oxysporum f. sp. phaseoli. Fitopatologia Brasileira 9:37-44.

Ribeiro RLD, Hagedorn DJ (1979) Screening for resistance to and pathogenic specialization of Fusarium oxysporum f. sp. phaseoli the causal agent of bean yellows. Phytopathology 69:272-276.

Schwartz HF, McMillan MS (1989) Occurrence of Fusarium wilt of beans in Colorado. Plant Disease 73:518.

Shi J, Mueller WC, Beckman CH (1992) Vessel occlusion and secretory activities of vessel contact cells in resistant or susceptible cotton plants infected with Fusarium oxysporum f. sp. vasinfectum. Physiological and Molecular Plant Pathology 40:133-147.

Van Der Molen GE, Beckman CH, Rodehorst E (1987) The ultrastructure of tylose formation in resistant banana following inoculation with Fusarium oxysporum f. sp. cubense. Physiological and Molecular Plant Pathology 31:185-200. 